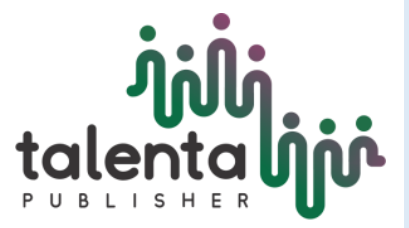

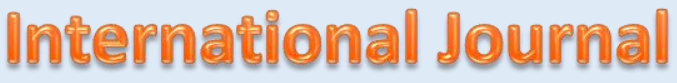 of Ecophysiology
}

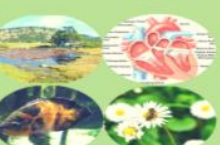

\section{cDNA Actin Isolated From Pandanus Sp.}

\author{
Dewi Indriyani Roslim ${ }^{1 *}$, and Herman ${ }^{1}$ \\ ${ }^{1}$ Departement of Biologi, Faculty Mathemathic and Science, Universitas Riau, Bina Widya Campus, Jl. \\ HR Soebrantas, Panam, Pekanbaru 28293, Riau, Indonesia.
}

\begin{abstract}
Actin is one of the reference genes that is often used as an internal control in gene expression analysis. This study aimed to isolate actin cDNA from Pandanus sp originated from Riau. Fresh leaves Pandanus sp. Lake Kajuik, Langgam District, Pelalawan Regency, Riau Province. Isolation of RNA, synthesis of total cDNA, amplification of actin genes used McDowell's designed degenerate primer (PlAc46S20/PlAc245N-20), electrophoresis, sequencing, and data analysis. Actin cDNA fragments obtained were $353 \mathrm{pb}$ in size, registered at GenBank and encoded 117 amino acids. Actin cDNA fragment consists of two exons and one introne. Specific actin primers from Riau Pandanus sp. can be designed based on sequences obtained for the purpose of analyzing certain gene expressions.
\end{abstract}

Keywords: actin cDNA, Lake Kajuik, Pandanus sp, RNA, Riau

Received 1 June 2019| Revised 1 July 2019 | Accepted 31 August 2019

\section{Introduction}

Pandanus sp. grows on Lake Kajuik, Langgam District, Pelalawan Regency, Riau Province, Indonesia. The genus often growth submerged and sank to $1.5 \mathrm{~m}$ below the surface of the water and resistant to flooding stresses and certainly contains tolerant genes inundation stress. To study the expression and role of these genes a reference gene is needed as an internal control. The reference genes are genes that are expressed in all tissues and the stages of development of eukaryotic plants. The expression is abundant and not affected by external conditions (Thellin et $a l, 1999)$. Because of its characteristics, the reference gene after being validated is often used as an internal control for the purposes of gene expression. Some examples of reference genes that have been validated and used as internal controls are actin genes (ACT), cassava (UBQ), glyceraldehyde-3-phosphate dehydrogenase (GAPDH), and tubulin (TUB) (Volkov et al, 2003; Jain et al, 2006; Caldana et al, 2007).

\footnotetext{
*Corresponding author at: Universitas Riau, Bina Widya Campus, Jl. HR Soebrantas, Panam, Pekanbaru 28293, Riau, Indonesia.

E-mail address: dewiindriyaniroslim@gmail.com 
The actin gene encodes the actin protein which is the constituent unit of actin filaments in the cytoskeleton. This actin protein is present in all eukaryotic cells (Thellin et al, 1999). Actin genes have been isolated from Arabidopsis thaliana plants (Volkov et al, 2003; McDowell et al, 1996). Melastoma malabathricum (Hannum et al, 2010) and Populus (Zhang et al, 2010). This study aims to isolate actin cDNA from Pandanus sp. from Riau.

\section{Materials and Methods}

Fresh leaves of Pandanus sp. were obtained from Lake Kajuik, Langgam District, Pelalawan Regency, Riau Province. The primers used were primary degenerate as follows PlAc46S-20: 5'ATG GTN GGN ATG GGN CAR AA-3 'and PlAc245N-20: 5'-GTD ATN ACY TGN TCN GG-3 CCR' (McDowell et al, 1996).

\section{Total RNA Isolation}

RNA isolation were treated with DEPC water to protect RNA from nuclease. Total RNA isolation of leaves and roots was carried out using Trizol reagents following the manufacturer's instructions (Invitrogen ${ }^{\circledR}$, Molecular Research Center, Inc., USA). The total RNA molecules obtained were then treated with DNase enzymes to remove DNA that might contaminate.

\section{Total cDNA synthesis}

Synthesis of cDNA (reverse transcription) was carried out using Superscript First-Strand synthesis system kit (Invitrogen $\AA$, USA) and primary oligo (dT) 21 . The reaction composition as follows: $5000 \mathrm{ng}$ RNA, 1x first strand buffer, $1 \mu \mathrm{M}$ primer Oligo (dT) 21, $0.5 \mathrm{mM}$ dNTPs, 10 $\mathrm{mM}$ DTT, 40 units of enzyme RTase, $0.01 \%$ water DEPC to total reaction $20 \mu$. The mixture was incubated on a PCR machine with the following program: $30^{\circ} \mathrm{C}$ for 10 minutes, $42^{\circ} \mathrm{C}$ for 50 minutes, $95^{\circ} \mathrm{C}$ for 5 minutes, and $20^{\circ} \mathrm{C}$ for 5 minutes.

\section{Total cDNA amplification using PCR (Polymerase Chain Reaction) Technique}

Amplification was carried out with PCR components including 1x PCR buffer (plus Mg2 +), 0.1 $\mathrm{mM}$ dNTPs, $0.2 \mu \mathrm{M}$ forward primer, $0.2 \mu \mathrm{M}$ reverse primer, $1 \mathrm{U}$ Dream Taq DNA polymerase enzyme (Thermo Scientific), $1 \mu \mathrm{l}$ total cDNA and water to the total reaction volume of PCR 50 $\mu$. The PCR program included: pre-PCR at $95{ }^{\circ} \mathrm{C}$ for 5 minutes, then followed by an amplification process of 35 cycles including stages of denaturation at $95{ }^{\circ} \mathrm{C}$ for 45 seconds, attachment of primer at $50^{\circ} \mathrm{C}$ for 45 seconds, and extension of primer or DNA synthesis at $72^{\circ}$ $\mathrm{C}$ for 1 minute 30 seconds. After that, post-PCR at $72{ }^{\circ} \mathrm{C}$ for 10 minutes. The results of the amplification were electrophoresed and photographed. 
Electrophoresis on 1.2\% agarose gel in electrophoresis buffer solution in the form of $1 \mathrm{x}$ buffer TBE (Tris-Borate-EDTA pH 8.0), voltage 65 volts for 30 minutes. The staining of DNA bands uses $5 \mu \mathrm{g} / \mathrm{ml}$ of ethidium bromide. The DNA tape visualized on a UV lamp (WiseUV WUVM20, Daihan Scientific) was then photographed using an Olympus SP500 UZ digital camera.

Nucleotide Tracing (Sequencing)

PCR products are sent to PT Genetika Science to be sequenced at 1st Base Malaysia. Sequencing was performed using a primer for PCR.

\section{Bioinformatics Analysis}

The DNA sequence data is then analyzed and aligned using the MEGA6, BLASTn (Basic Local Alignment Search Tool) program on the web site http: //www.ncbi. nlm.nih.gov/ BLAST (Altschul et al, 1997), and ExPASy-Translate tools on the web site http://www.expasy.ch/tools/dna.html (Gasteiger et al, 2003). Phylogenetic trees are made using the Neighbor Joining method with Kimura-2-Parameter model and 1000 times bootstrap. Sequences of several accessions were used to make phylogenetic trees obtained from the GenBank database.

\section{Result and Discussion}

The cDNA fragment of actin encoding has been obtained with a size of around $370 \mathrm{pb}$ (Figure 1). Sequencing the cDNA fragment obtained $353 \mathrm{pb}$ (Figure 2) and was registered with the GenBank database with accession number MG836260.

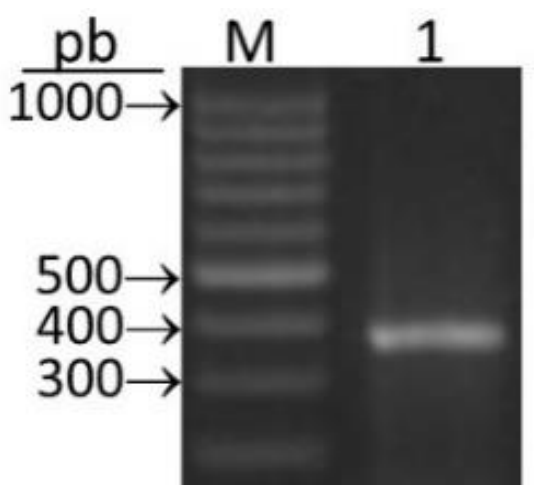

Figure 1. Fragment of cDNA actin isolated from Pandanus sp. $M=1 \mathrm{~kb}$ DNA ladder;

$1=\mathrm{cDNA}$ fragment code for actin 


\section{$>$ MG836260 Pandanus sp clone Riau actin mRNA, partial sequence GGCACCACACTTTCTACAATGAGCTTCGTGTGGCACCAGAAGAACATCCTGTTCTTCTGACAGAAGCCCC TCTCAACCCCAAGGCCAACAGGGAGAAGATGACACAAATCATGTTTGAGACCTTCAATGTCCCCGCCATG TATGTTGCAATTCAAGCCGTCCTTTCCCTTTATGCCAGTGGTCGTACCACAGGTATTGTGCTAGATTCTG GTGATGGGGTCAGTCATACTGTGCCAATTTATGAGGGTTATGCGCTTCCTCATGCCATTCTCCGGCTTGA TCTTGCGGGAAGAGACCTGACAGATTGCCTTATGAAGATCCTCACAGAGAGAGGCTACTCGTTCACAACC $\mathrm{ACT}$}

Figure 2. Sequence of cDNA actin iolated from Pandanus sp.

BLAST analysis in the cDNA sequence showed that cDNA sequences of actin encoding in Pandanus sp. had similarities up to $88 \%$ with actin cDNA sequences from several plant accessions (Table 1). But none of these accessions are members of the genus Pandanus. Therefore the sequences obtained in this study are cDNA sequences of actin encoders which were first reported from the genus Pandanus.

Table 1. BLAST analysis on cDNA sequences of actin encoding in Pandanus sp. plants from Riau.

Table 1. BLAST analysis cDNA sequence isolated from Pandanus sp.

\begin{tabular}{|c|c|c|c|c|c|c|}
\hline Description & $\operatorname{Max}$ & Total score & Query cover & Evalue & Ident & Accession \\
\hline Lilium regale & 437 & 437 & $99 \%$ & 9e-119 & $88 \%$ & JX826390.1 \\
\hline Lilium davidii & 432 & 432 & $99 \%$ & $4 \mathrm{e}-117$ & $87 \%$ & KP861871.1 \\
\hline Lilium hybrid & 423 & 423 & $99 \%$ & $2 \mathrm{e}-114$ & $87 \%$ & KU176087.1 \\
\hline Tulipa fosteriana & 423 & 423 & $99 \%$ & $2 \mathrm{e}-114$ & $87 \%$ & KM507834.1 \\
\hline Magnolia grandiflora & 421 & 421 & $100 \%$ & $7 e-114$ & $86 \%$ & KJ579271.1 \\
\hline Gagea nigra & 421 & 421 & $100 \%$ & $7 e-114$ & $86 \%$ & KR633144.1 \\
\hline Magnolia denudata & 421 & 421 & $100 \%$ & $7 e-114$ & $86 \%$ & AF281323.1 \\
\hline Tulipa gesneriana & 419 & 419 & $99 \%$ & $2 \mathrm{e}-113$ & $86 \%$ & AB456684.1 \\
\hline $\begin{array}{l}\text { Cіппатотит } \\
\text { camphora }\end{array}$ & 416 & 416 & $100 \%$ & $3 e-112$ & $86 \%$ & KM086737.1 \\
\hline Galtonia saundersiae & 414 & 414 & $99 \%$ & $1 \mathrm{e}-111$ & $86 \%$ & KM510380.1 \\
\hline
\end{tabular}


In addition, the results of the BLAST analysis showed that the cDNA sequences obtained in this study consisted of two exons and introns. The two exons encode 117 amino acids.

Phylogenetic trees built on cDNA sequences (Figure 3) and amino acids (Figure 4) actin encoding indicate that cDNA sequences of actin encode from Pandanus sp. form the same group as fellow actin encoding sequences, separate from the polyubicuitin coding sequences as comparison. These results support the results of the BLAST analysis that the cDNA sequences obtained in this study are part of the actin encode.

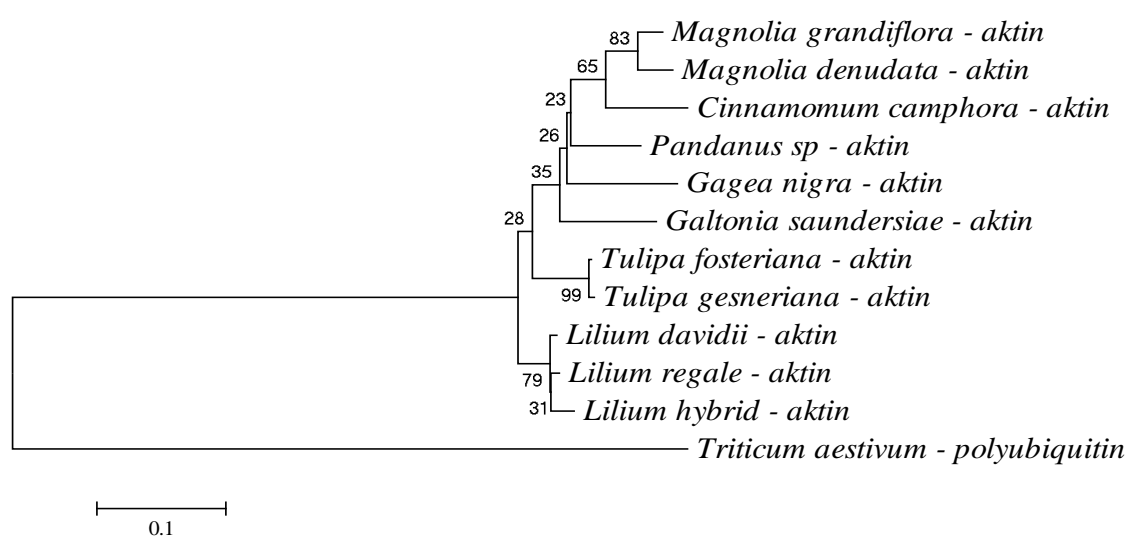

Figure 3. Phylogenetic tree based on cDNA sequence encode for actin

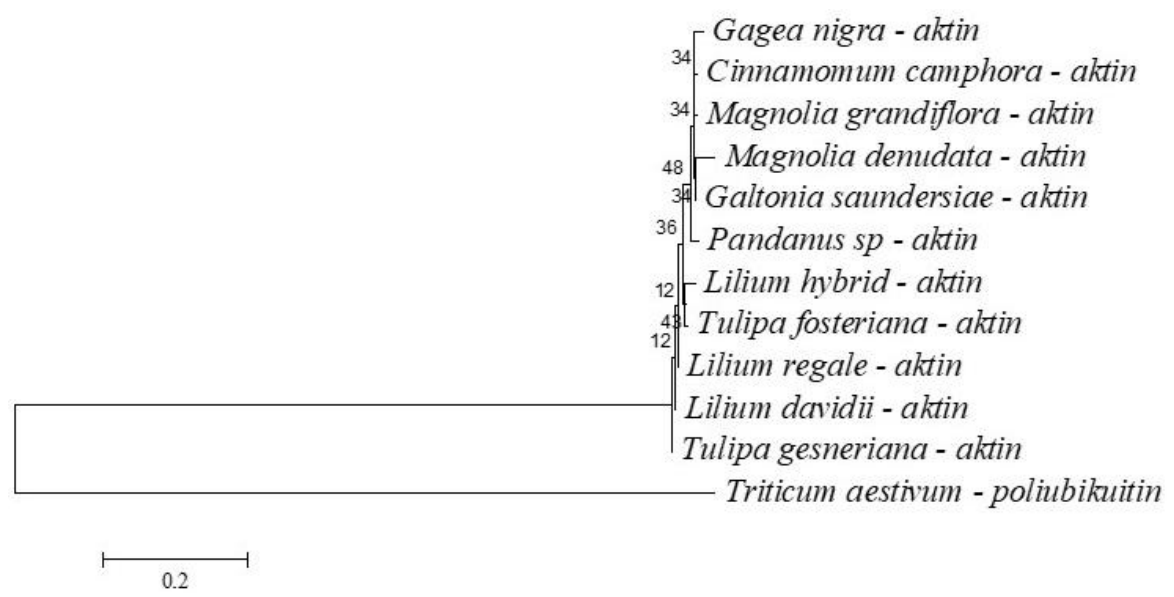

Figure 4. Phylogenetic tree based on amino acid sequence encode actin 


\section{Conclussion}

The actin cDNA fragments obtained in this study were $353 \mathrm{pb}$ in size and were registered at GenBank and encoded 117 amino acids. This actin cDNA fragment consists of two exons and one introne. Specific actin primers from Riau Pandanus sp. can be designed based on sequences obtained for the purpose of analyzing certain gene expressions.

\section{Aknowledgement}

This research was funded by the Directorate of Research and Community Service (DRPM), Ministry of Research, Technology and Higher Education, Republic of Indonesia through University Basic Research Grant (PDUPT). We also thanks to the LPPM University of Riau for facilitating this research.

\section{References}

[1] Altschul SF, Madden TL, Schaffer AA, Zhang J, Zhang Z, Miller W, Lipman DJ. Gapped BLAST and PSI-BLAST. A new generation of protein database search programs. 1997, Nucleic Acid Res. 25: 3389-3402.

[2] Caldana C, Scheible WR, Mueller-Roeber B, Ruzicic S. A quantitative RT-PCR platform for high throughput expression profiling of 2500 rice transcription factors. 2007, Plant Methods 3:7 doi: 10.1186/1746-4811-3-7.

[3] Gasteiger E, Gattiker A, Hoogland C, Ivanyi I, Appel RD, Bairoch A. ExPASy: the proteomics server for in-depth protein knowledge and analysis. 2003, Nucleic Acids Res. 31: 3784-3788.

[4] Hannum S, Akashi K, Suharsono UW, Hartana A, Yokota A, Suharsono. 2010. Isolasi fragmen cDNA dari gen penyandi aktin dari Melastoma malabathricum. Makara Sains 14(2): 163-167.

[5] Jain M, Nijhawan A, Tyagi AK, Khurana JP. Validation of housekeeping genes as internal control for studying gene expression in rice by quantitative real-time PCR. 2006, Biochemical and Biophysical Research Communications 345: 646651.

[6] McDowell JM, Huang S, McKinney EC, An Y-Q, Meagher RB. Structure and evolution of the actin gene family in Arabidopsis thaliana. 1996, Genetics 142: 587-602.

[7] Thellin O, Zorzi W, Lakaye B, Borman BD, Coumans B, Hennen G, Grisar T, Igout A, Heinen E. Housekeeping genes as internal standards: use and limits. 1999, J. Biotechnol. 75:291-295.

[8] Volkov RA, Panchuk II, Schoffl. Heat-stress-dependency and developmental modulation of gene expression: the potential of house-keeping genes as internal 
standards in mRNA expression pro®ling using real-time RT-PCR. 2003, J. Exp. Bot. 54(391): 2343-2349. DOI: 10.1093/jxb/ erg244.

[9] Zhang D, Du Q, Xu B, Zhang Z, Li B. 2010. The actin multigene family in Populus: organization, expression and phylogenetic analysis. Mol. Genet. Genomics 284(2): 105-19. doi: 10.1007/s00438-010-0552-5. 